1. There was never any ocular disease.

2. Complaints ceased when the troops entered Palestine.

I do not know where vitamin A was obtained in Palestine, though there was an abundance of exçellent fruit. . In fact one of the most remarkable incidents which came to notice was that a battery was engaged near Jerusalem shelling the Turks and native children were selling fruit to the gunners during the engagement.

I am, Yours truly,

JAMES'W. BARRETT.

103-105, Colliñs Street,

Melbourne, C.1

December 29, 1941.

\title{
THE DIAGNOSTIC SIGNIFICANCE OF RETRO-BULBAR NEURITIS
}

To the Editors of THE BRITISH JOURNAL OF OPHTHALMOLOGY.

DEAR SIRS, - With regard to the letter from your correspondent Allan Briggs, may I say that we must all feel that it is a reproach to our profession that the origin of the four diseases mentioned, viz., retro-bulbar neuritis, rheumatoid arthritis, recurrent iritis and disseminated sclerosis is still so obscure.

We are often obliged, on this account, to stand by helplessly while we watch these miserable conditions go from bad to worse, for want of an efficient remedy.

That there may be a "silent" sinusitis, i.e., without signs or symptoms, as a remote focus of infection, has often been reported, a most striking example being the one reported by me 'in the February Brit. Jl. of Ophthat. this year.

I would like to suggest to Mr. Briggs that, while he is waiting for some new advance of medical knowledge in the future, it would be -wise, in the meantime, thoroughly to explore the possibilities of the hidden nasal sepsis to which my paper drew attention.

If he does so, he will find, as I have, that it throws light on scores of otherwise obscure cases.

Yours faithfully, ROSA FORD.

88, HARLEY STREET, W.1

May 9, 1942. 